\title{
A new genus of small Minnow Mayflies (Insecta : Ephemeroptera : Baetidae) with six new species from New Guinea and New Britain
}

\author{
C. R. Lugo-Ortiz 1 \\ W. P. McCafferty 1
}

Keywords : Ephemeroptera, Baetidae, New Guinea, New Britain, Papuanatula, new genus, new species.

\begin{abstract}
Papuanatula, n. gen. (Ephemeroptera : Baetidae), is described from New Guinea and New Britain and based on both larvae and adults. Larvae of Papuanatula are distinguished by having basally narrow and distally broad antennal scapes; glossae shorter than paraglossae ; segment 3 of labial palps more convex laterally than medially ; ventral long, somewhat robust, simple seta subdistally on tarsi ; gills on abdominal segments 2-7; reduced medial caudal filament ; and absence of hindwingpads. Adults have double marginal intercalaries in the forewings, lack hindwings, and males possess a sclerotized process between the genital forceps. Five new species are described from New Guinea $[P$. bessa $\mathbf{n}$. sp., P. copis $\mathrm{n}$. sp., P. lenos n. sp., P. plana n. sp., and P. tu$b e r$, n. sp. (type species)] and one new species named from New Britain (P. vaisisi n. sp.). An identification key to the larvae of the six new species is included.
\end{abstract}

Un genre nouveau et six espèces nouvelles d'Ephémères Pisciforma (Insecta : Ephemeroptera : Baetidae) de Nouvelle Guinée et de Nouvelle Angleterre

Mots-clés : Ephemeroptera, Baetidae, Nouvelle Guinée, Nouvelle Angleterre, Papuanatula, genre nouveau, espèces nouvelles.

Papuanatula, n. gen. (Ephemeroptera : Baetidae), est décrit de Nouvelle Guinée et de Nouvelle Angleterre à partir de larves et d'adultes. Les larves de Papuanatula se distinguent par: des scapes antennaires étroits à la base et élargis distalement; des glosses plus courtes que les paraglosses; des palpes labiaux dont le segment 3 présente un bord externe plus convexe que le bord interne; une longue soie simple, ventrale, assez robuste, en position subdistale sur les tarses; des branchies sur les segments abdominaux 2-7; un filament caudal médian réduit; et l'absence de fourreaux alaires postérieurs. Les adultes présentent des intercalaires marginales doubles aux ailes antérieures et sont dépourvus d'ailes postérieures; les mâles possèdent un processus sclérifié entre les forceps génitaux. Cinq espèces nouvelles sont décrites de Nouvelle Guinée [P. bessa n. sp., P. copis $\mathrm{n}$. sp., P. lenos n. sp., P. pla$n a$ n. sp., et $P$. tuber $\mathbf{n}$. sp. (espèce type)] ainsi qu'une espèce de Nouvelle Angleterre (P. vaisisi $\mathbf{n}$. sp.). Une clé d'identification des larves des six espèces nouvelles est proposée.

\section{Introduction}

The Ephemeroptera family Baetidae has been poorly documented in New Guinea and New Britain. Ulmer (1920) provided the first baetid report from New Guinea for Cloeon fluviatile Ulmer. Subsequent baetid reports from New Guinea involve only that of Baetis sogeriensis Harker (Harker 1954) and Cloeon papuanum

1. Department of Entomology, Purdue University, West Lafayette, IN 47907, USA.

E-mail : carlos_lugo-ortiz@entem.purdue edu van Bruggen (van Bruggen 1957, 1960). Demoulin (1969) reported four unnamed species from New Britain that he assigned to Baetis Leach and Pseudocloeon Klapálek. Harker's (1954), Harker's (1954) and Demoulin's (1969) assignment of baetids to both Baetis and Pseudocloeon are necessarily provisional because the concept of Baetis has been considerably modified recently (see, e.g., Waltz \& McCafferty 1987a, 1997 ; McCafferty \& Waltz 1990, 1995 ; Waltz et al. 1994) and because the concept of Pseudocloeon has been restricted to $P$. kraepelini Klapálek (Waltz \& McCafferty 1985, 1987b). 
We herein describe a new genus and five new species of Baetidae from New Guinea. We also assign one of Demoulin's (1969) Pseudocloeon species from New Britain to the new genus and give it a formal name. We compare the new genus to other Southeast Asian genera and provide an identification key to the larvae of the new species. Except where otherwise noted, materials examined are housed in the Purdue Entomological Research Collection, West Lafayette, Indiana, USA.

\section{Papuanatula Lugo-Ortiz \& McCafferty, n. gen.}

\subsection{Description}

LARVA

- Head

Antennal scapes (Fig. 8) basally narrow, distally broad.

Labrum (Figs. 9, 25, 33) narrower basally than distally, with distal anterior submarginal row of long, fimbriate setae.

Hypopharynx (Fig. 10) with lingua distally broad and convex, with abundant minute, fine, simple setae scattered over surface ; superlinguae distally concave, with abundant minute, fine, simple setae scattered over surface.

Left mandible (Figs. 1, 11, 19, 26) with incisors fused, but in some discernible ; prostheca basally narrow, distally broad and with blunt denticles.

Right mandible (Figs. 2, 12, 20, 27) with two sets of incisors ; outer set poorly denticulate, distally blunt (Figs. 2, 27) or bladelike (Figs. 12, 20) ; inner set with two to three distal denticles ; prostheca basally and distally slender, distally with acute denticles.

Maxillae (Figs. 3, 13, 28, 36) with four blunt denticles on crown of galealaciniae ; palps two segmented.

Labium (Figs. 4, 14, 21, 29, 37) with glossae shorter and narrower than paraglossae ; paraglossae subrectangular, distally with three rows of long, distally pectinate setae ; palps three segmented ; palp segment 3 more convex laterally than medially.

-Thorax

Hindwingpads absent.

Legs (Figs. 15, 22) without villopore ; femora anterodorsally with submarginal row of long, somewhat robust, simple setae, and ventrally with sparse short, stout, simple setae ; tibiae anterodorsally with submarginal row of long, somewhat robust, simple setae, and ventrally with sparse short, stout, simple setae ; tarsi anterodorsally with submarginal row of long, somew- hat robust, simple setae, and ventrally with sparse short, stout, simple setae and long, somewhat robust, subdistal seta ; tarsal claws with one row of denticles and long, somewhat robust, simple seta laterally.

-Abdomen

Terga dorsally with (Figs. 16, 34) or without tubercles.

Gills (Figs. 6, 17, 24, 30) on segments 2-7, platelike, held dorsolaterally.

Paraprocts marginally with minute spines (Figs. 7, 18) or smooth (Fig. 35), distomedially with (Fig. 7) or without (Figs. 18, 35) subtriangular process.

\section{ADULT}

- Head

Male turbinate eyes round to ovoid, mounted on broad or slender stalks.

- Thorax

Mesothorax without dorsomedial pointed process.

Forewings (Fig. 31) with double marginal intercalaries.

Hindwings absent.

- Abdomen

Male genitalia (Fig. 32) with sclerotized process between forceps ; segment 1 short, subcylindrical, medially produced ; segment 2 elongate, arched, basally broader than apically ; segment 3 short, ovoid, distinct from segment 2.

- Type species

Papuanatula tuber Lugo-Ortiz \& McCafferty, n. sp. - Included species

Papuanatula bessa Lugo-Ortiz \& McCafferty, n. sp. (larva ; male, female subimagos) ; P. copis Lugo-Ortiz \& McCafferty, n. sp. (larva) ; P. lenos Lugo-Ortiz \& McCafferty, n. sp. (larva); P. plana Lugo-Ortiz \& McCafferty, n. sp. (larva ; male, female adults) ; $P$. tuber Lugo-Ortiz \& McCafferty, n. sp. (larva); P. vaisisi Lugo-Ortiz \& McCafferty (larva).

\section{- Distribution}

New Britain, New Guinea.

- Etymology

The generic name is an arbitrary combination of letters incorporating the nouns Papua and natula (Latin for «little daughter»). It thus may be taken as «little daughter of Papua.» The gender is feminine.

\section{- Discussion}

Larvae of Papuanatula are distinguished from those of other Oriental and Australian small minnow may- 

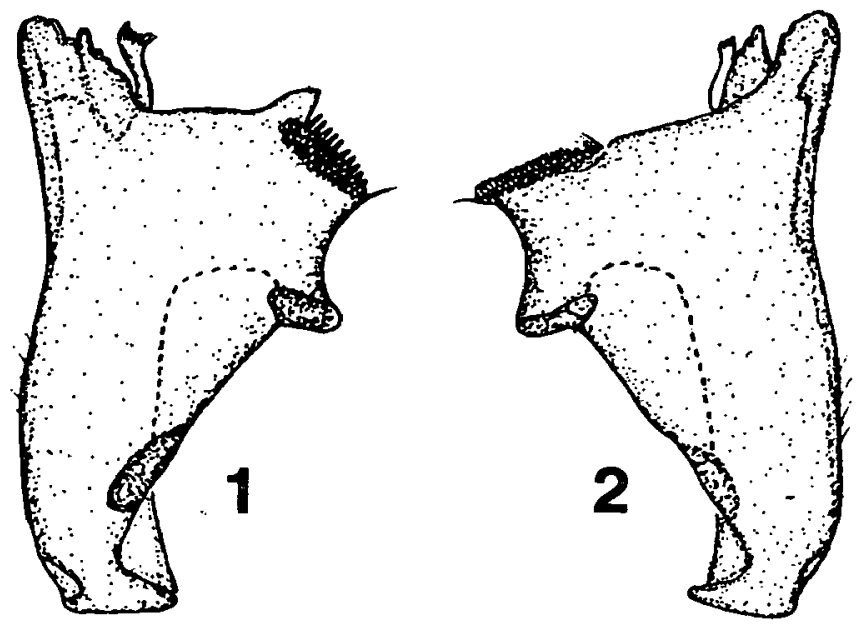

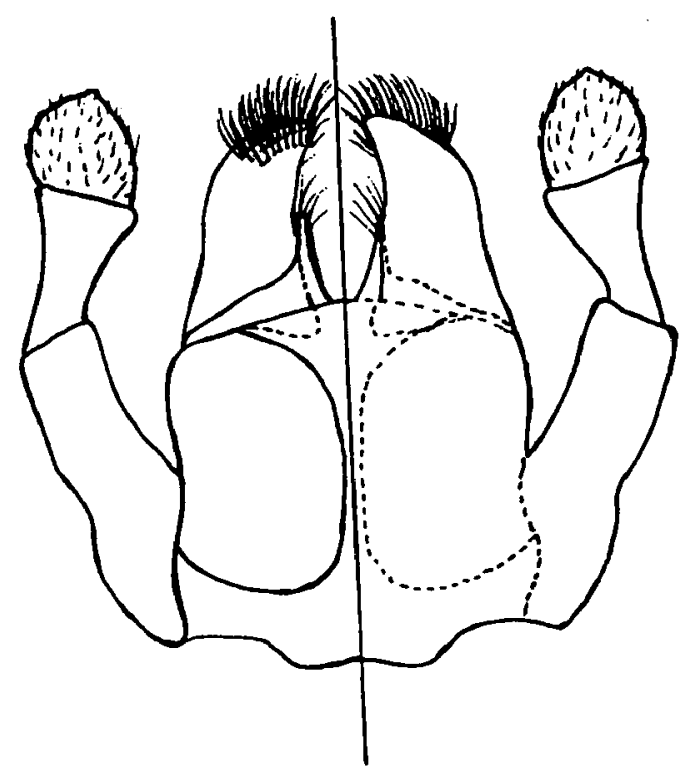

4

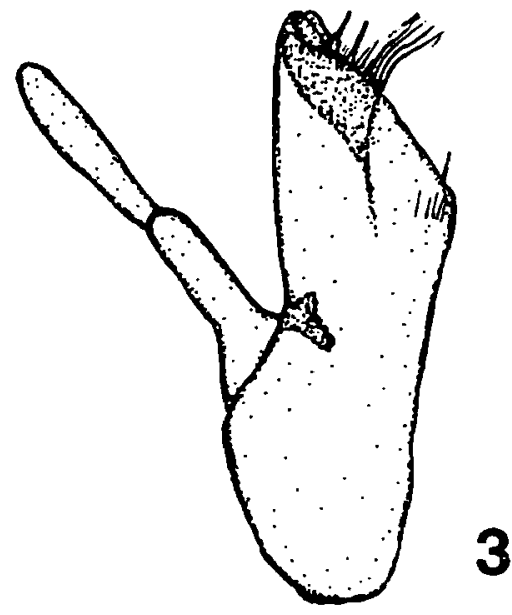

3

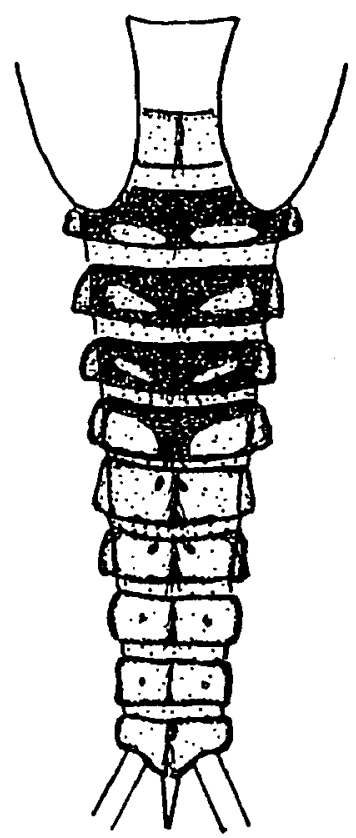

5

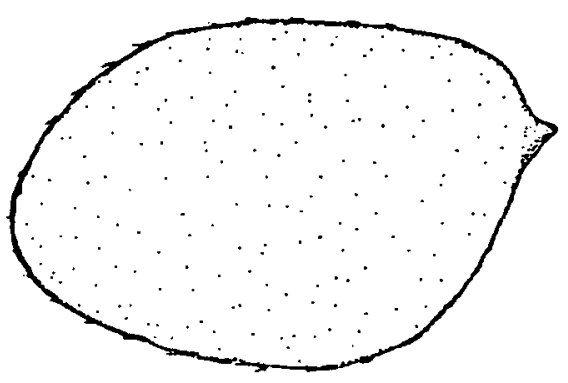

6

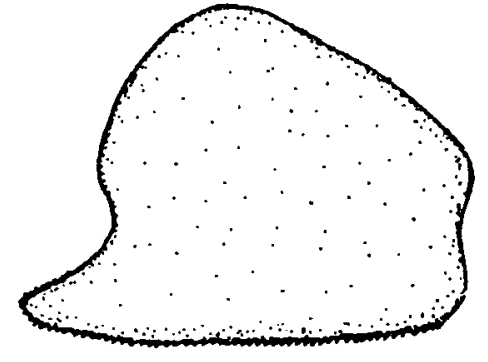

7

Figs. 1 to 7. Larval structures of Papuanatula bessa. 1 : left mandible. 2 : right mandible. $3:$ right maxilla. 4 : labium (left : ventral ; right : dorsal). 5 : abdomen (dorsal). 6 : gill 4.7 : paraproct.

Figs 1 à 7. Structures larvaires de Papuanatula bessa. $1:$ mandibule gauche. $2:$ mandibule droite. $3:$ maxille droite. $4:$ labium (à gauche : vue ventrale ; à droite : vue dorsale). 5. abdomen (vue dorsale). 6. $4 \mathrm{e}$ branchie. 7. paraprocte.

flies by the following combination of characteristics : basally narrow and distally broad antennal scapes (Fig. 8 ) ; basally narrow and distally broad labrum with distal anterior submarginal row of fimbriate setae (Figs. 9, 25,33 ) ; distally concave superlinguae (Fig. 10) ; glossae shorter than paraglossae (Figs. 4, 14, 21, 29, 37) ; segment 3 of the labial palps being laterally more convex than medially (Figs. 4, 14, 21, 29, 37) ; absence of hindwingpads ; presence of long, simple setae submarginally on the legs, and presence of a long, simple seta subdistally on the tarsi (Figs. 15, 22) ; absence of first pair of gills ; and reduced medial caudal filament. Male adults of Papuanatula are distinguished from other baetids with double marginal intercalaries in the forewings and without hindwings by the combination of a sclerotized process between the genital forceps and forceps segment 1 medially produced and forceps segment 3 clearly articulated from segment 2 (Fig. 32).

Possible phylogenetic relationships of Papuanatula are difficult to ascertain at this time. The presence of a long, simple seta subdistally on the larval tarsi is shared with the Oriental genera Jubabaetis Müller-Liebenau (Müller-Liebenau 1980 : Fig. 1i, j), Liebebiella Waltz \& McCafferty (Waltz \& McCafferty 1987b : Fig. 6), and Platybaetis Müller-Liebenau (Müller-Liebenau 1980 : Fig. $6 \mathrm{f}, \mathrm{g}$ ). Larvae of Liebebiella and Platybaetis however, possess the villopore (Waltz \& 


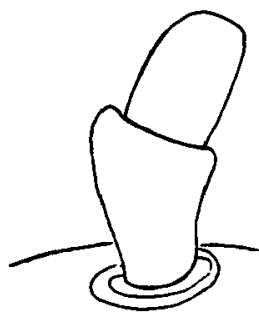

8
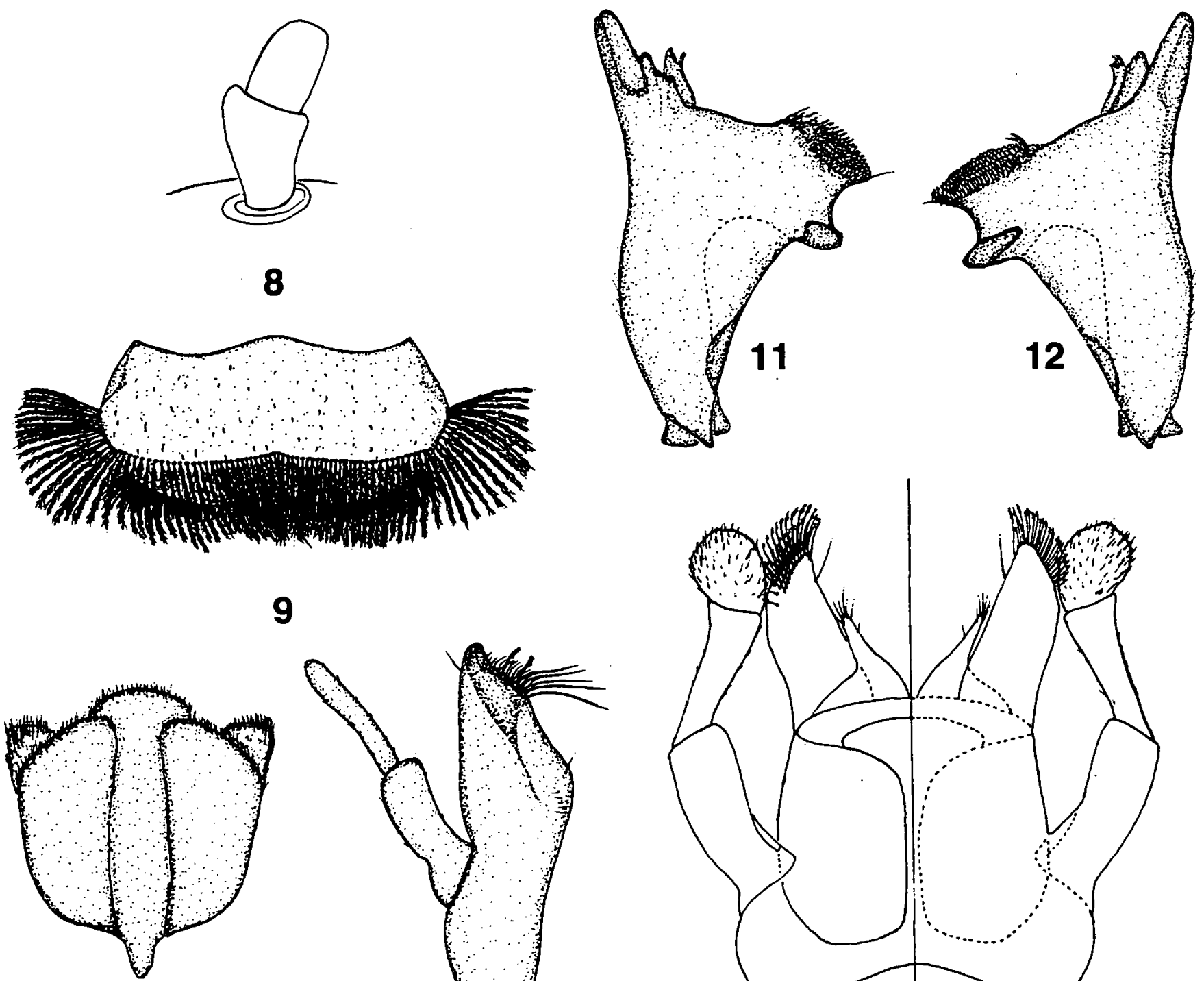

9

10

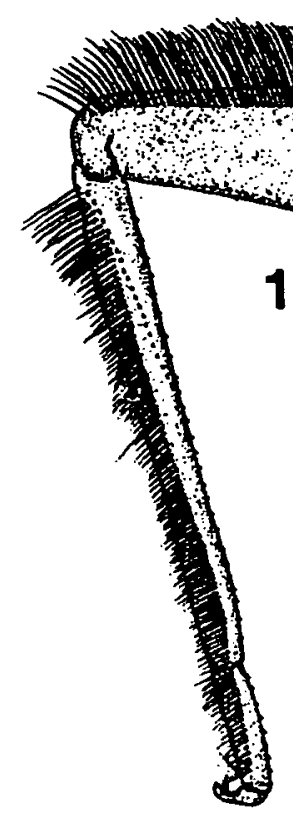

13

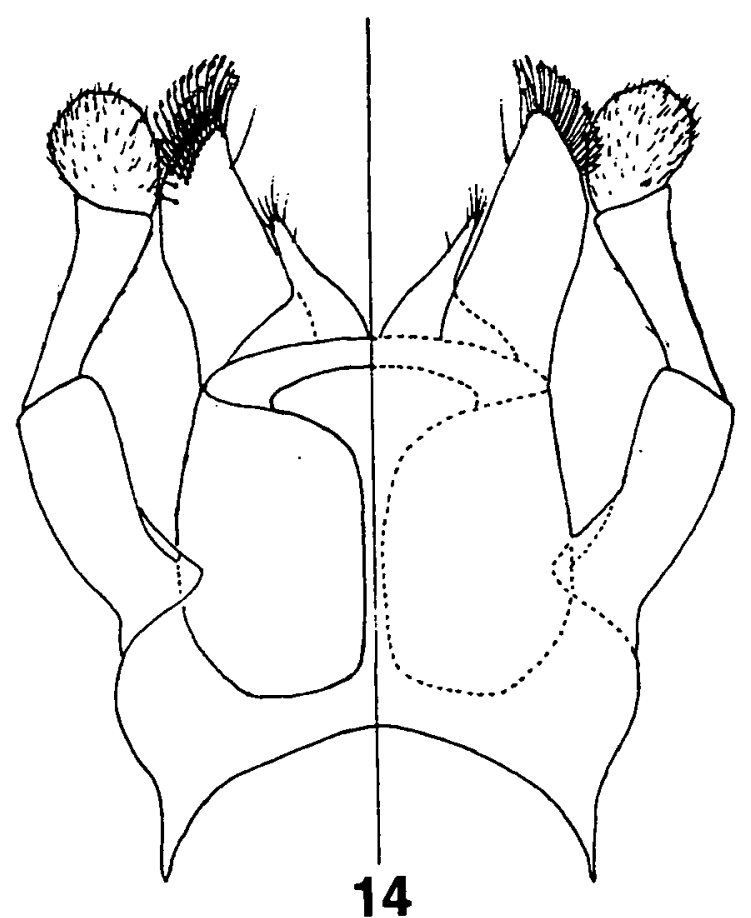

14

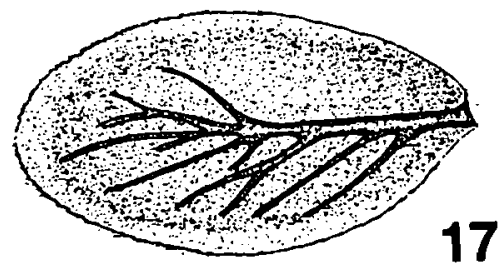

17

Figs. 8 to 18. Larval structures of Papuanatula copis. 8 : antennal scape and pedicel. $9:$ labrum (dorsal). $10:$ hypopharynx. 11 : left mandible. 12 : right mandible. 13 : right maxilla. 14 : labium (left : ventral ; right : dorsal). 15 : right foreleg. 16 : abdomen (lateral). $17:$ gill 4.18 : paraproct.

Figs 8 à 18. Structures larvaires de Papuanatula copis. 8 : scape et pédicelle antennaires. 9 : labre (vue dorsale). 10 : hypopharynx. $11:$ mandibule gauche. $12:$ mandibule droite. $13:$ maxille droite. $14:$ labium (à gauche : vue ventrale ; à droite : vue dorsale). $15:$ patte antérieure droite. $16:$ abdomen (vue latérale). $17: 4^{\mathrm{e}}$ branchie. $18:$ paraprocte. 


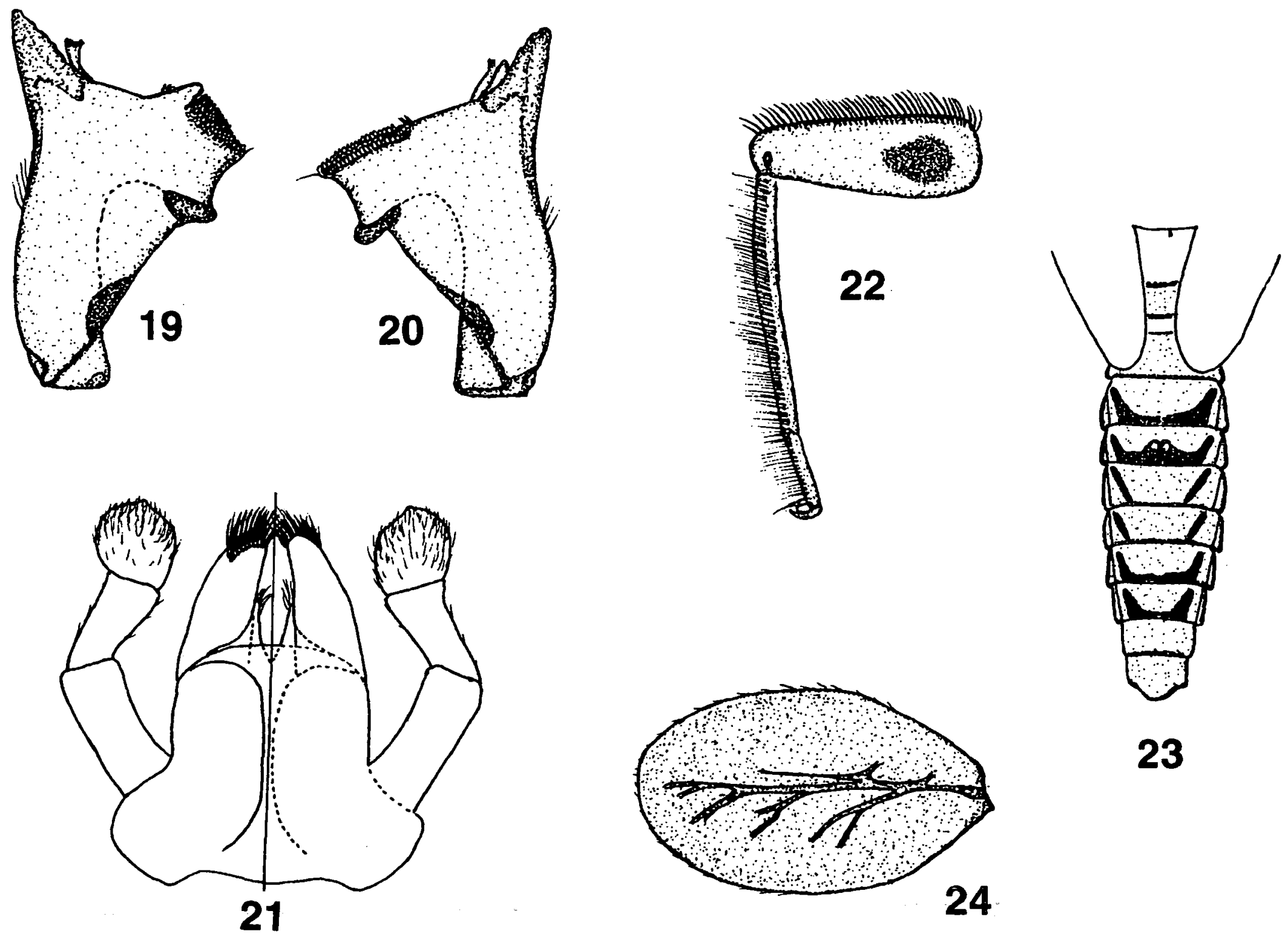

Figs. 19 to 24. Larval structures of Papuanatula lenos. 19 : left mandible. 20 : right mandible. 21 : labium (left : ventral ; right : dorsal). 22 : right foreleg. 23 : abdomen (dorsal). 24 : gill 4.

Figs 19 à 24. Structures larvaires de Papuanatula lenos. 19 : mandibule gauche. $20:$ mandibule droite. 21 : labium (à gauche : vue ventrale ; à droite : vue dorsale). $22:$ patte antérieure droite. $23:$ abdomen (dorsal). $24: 4^{\mathrm{e}}$ branchie.

McCafferty 1987 : Figs. 4, 5) and hence belong to the Baetis complex of genera (see, e.g., Lugo-Ortiz \& McCafferty 1997, Waltz \& McCafferty 1997), but it is possible that the subdistal tarsal seta in larvae of $\mathrm{Pa}$ puanatula indicates a close relationship with Jubabaetis. There may be other explanations for the seemingly anomalous presence of the tarsal seta, including adaptive homoplasy.

The presence of a sclerotized process between the male genital forceps of Papuanatula would indicate that the genus is related to either Labiobaetis or Pseudocloeon kraepelini. The morphology of the male genital forceps of Labiobaetis, however, is different from that of Papuanatula in that segment 1 is not medially produced and segment 3 is globular and semifused to segment 2 (Morihara \& McCafferty 1979 : Figs. 1218). In the male genital forceps of Papuanatula, segment 1 is medially produced and segment 3 is ovoid and well defined (Fig. 32). In addition, as is the case with Liebebiella and Platybaetis, Labiobaetis belongs to the Baetis complex of genera because its larvae possess the villopore, and larvae of Papuanatula lack that structure. In $P$. kraepelini, the sclerotized process between the male genital forceps (Waltz \& McCafferty 1985 : Fig. 3) is broader and less produced than in $\mathrm{Pa}$ puanatula (Fig. 32). Moreover, the anal region of the forewings of P. kraepelini (Waltz \& McCafferty 1985 : Fig. 2) is more angular than in Papuanatula (Fig. 31). 


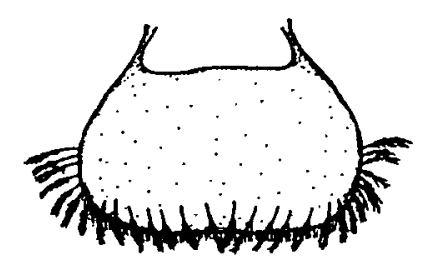

25

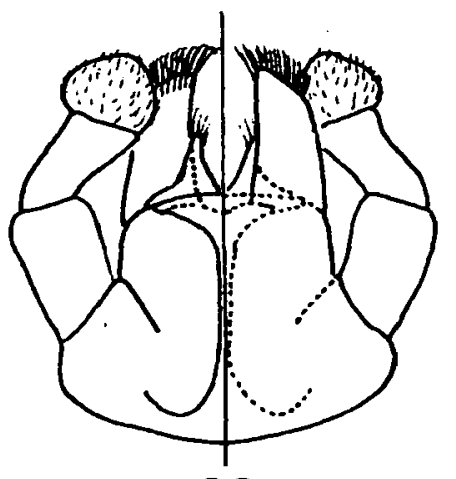

29
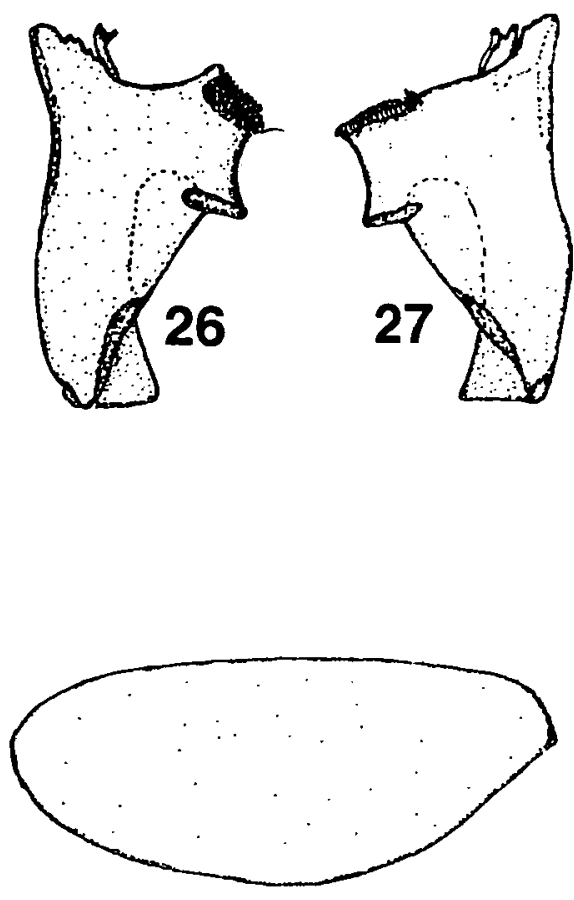

30
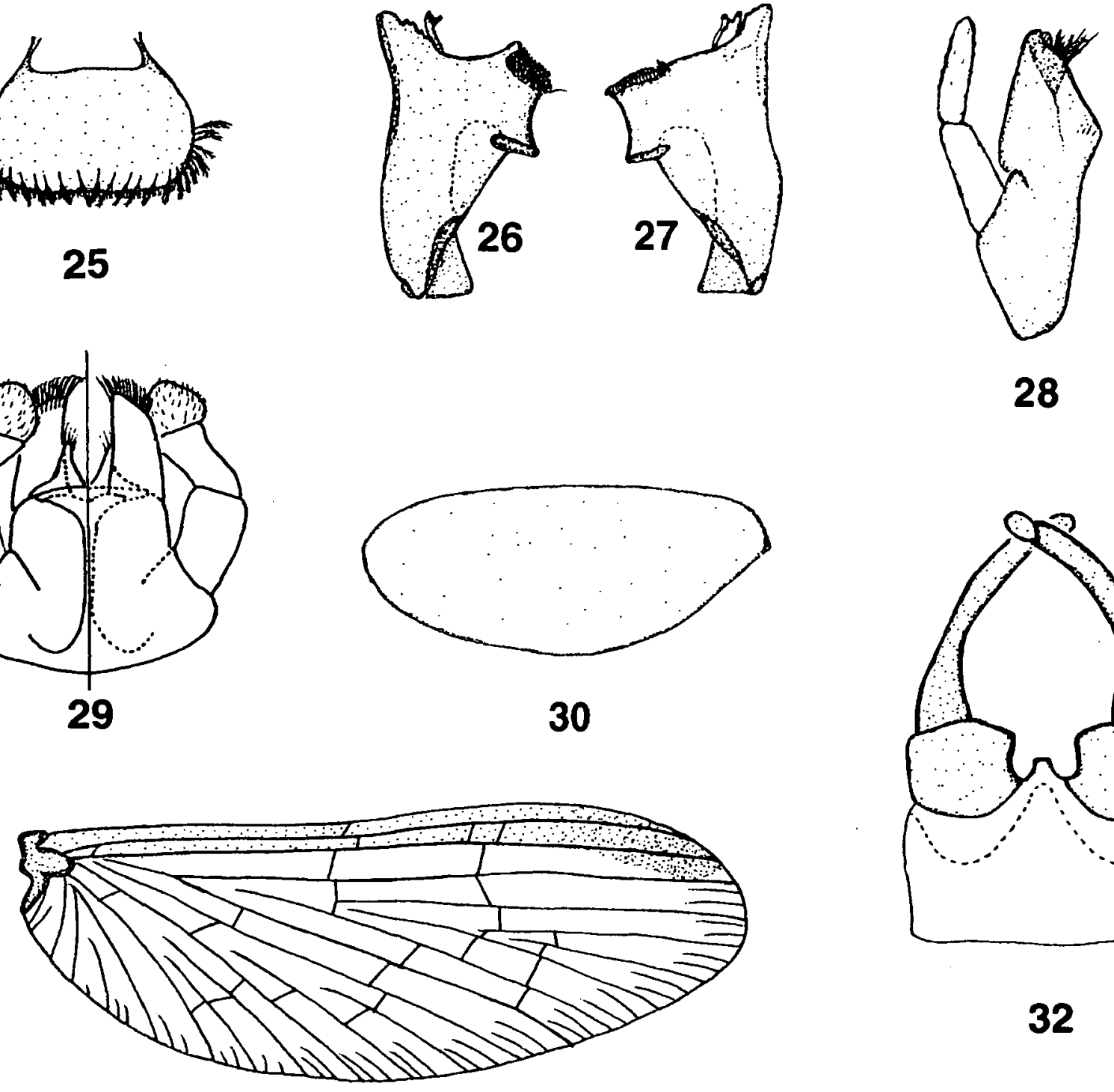

28

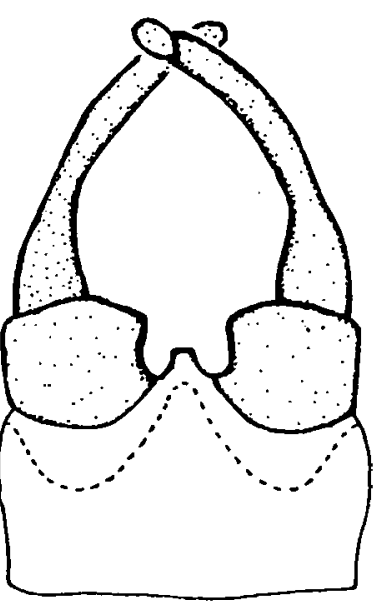

32

31

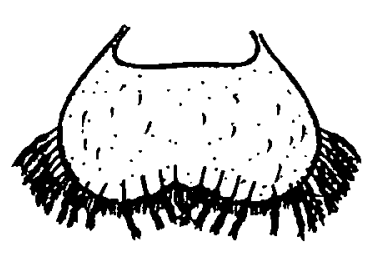

33

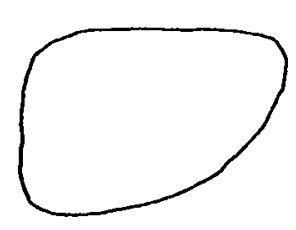

35

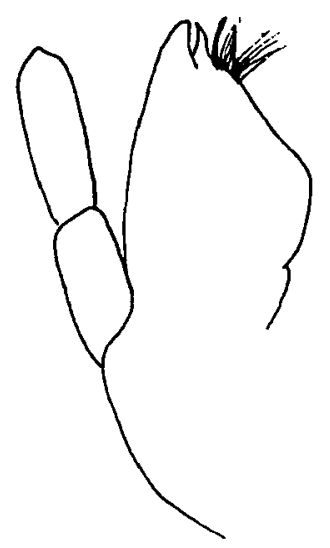

36

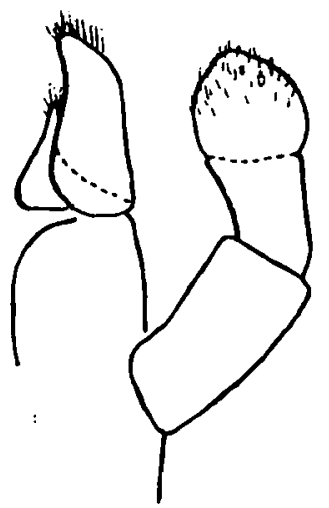

37

34

Figs. 25 to 37. Structures of Papuanatula plana, P. tuber, and P. vaisisi. Figs. 25 to 30. Papuanatula plana, larva. $25:$ labrum (dorsal). $26:$ left mandible. 27 : right mandible. 28 : right maxilla. 29 : labium (left : ventral ; right : dorsal). 30 : gill 4 . Figs 31 to 32 . Papuanatula plana, male adult. 31 : forewing. 32 : genitalia. Figs. 33 to 35 . Papuanatula tuber, larva. 33 : labrum (dorsal). $34:$ abdomen (lateral). $35:$ paraproct. Figs. 36 to 37. Papuanatula vaisisi, larva [after Demoulin (1969)]. 36 : right maxilla. 37 : labium (dorsal).

Figs 25 à 37. Structures de Papuanatula plana, P. tuber, et $P$. vaisisi. Figs 25 à 30. Papuanatula plana, larve. $25:$ labre (vue dorsale). $26:$ mandibule gauche. 27 : mandibule droite. $28:$ maxille droite. $29:$ labium (à gauche : vue ventrale ; à droite : vue dorsale). $30: 4$ e branchie. Figs 31 à 32. Papuanatula plana, adulte mâle. 31 : aile antérieure. 32. genitalia. Figs 33 à 35. Papuanatula tuber, larve. $33:$ labre (vue dorsale). 34 : abdomen (vue latérale). $35:$ paraprocte. Figs 36 à 37. Papuanatula vaisisi, larve [d'après Demoulin (1969)]. $36:$ maxille droite. $37:$ labium (vue dorsale). 
Based on these significant morphological differences, we do not consider Papuanatula to be related to either Labiobaetis or P. kraepelini. There remains insufficient basis for establishing the possible equivalency of Pseudocloeon (whose larvae are unknown) with any other nominal genera of Baetidae. If such equivalency exists, it will have to be proven through rearing of $P$. kraepelini.

Larvae of Papuanatula show adaptive characterization that typifies a wide array of often unrelated baetids found in fast-flowing streams, such as Acanthiops Waltz \& McCafferty, Acentrella Bengtsson, Baetodes Needham \& Murphy, Demoreptus Lugo-Ortiz \& McCafferty, Liebebiella, Platybaetis, Prebaetodes LugoOrtiz \& McCafferty, and Tanzaniella Gillies. Those characteristics may include relatively long, outstretched legs with long setae at least on the dorsal margin of the femora ; somewhat twisted tarsi ; reduction or loss of gills ; poorly tracheated or untracheated gills ; reduction or loss of medial setae on the cerci ; and reduction or loss of the medial caudal filament. The development of dorsal abdominal tuberculation to various degrees is also possible among such torrenticulous, or at least rheophilic, baetids.

\subsection{Papuanatula bessa Lugo-Ortiz \& McCafferty, n. sp.}

\section{- Description}

\section{LARVA}

Body length : $3.9-4.9 \mathrm{~mm}$; caudal filaments length : 6.0-6.5 mm.

- Head

Coloration medium yellow-brown to medium brown, with medium yellow-brown vermiform markings in frons and vertex.

Antennae approximately $1.5 \mathrm{x}$ length of head capsule.

Labrum (similar to Fig. 9) dorsally with distal submarginal row of 30-35 long, fimbriate setae.

\section{Hypopharynx similar to Figure 10.}

Left mandible (Fig. 1) with large, apically blunt outer incisor, and inner incisor with four small denticles ; subtriangular process at base of mola well developed.

Right mandible (Fig. 2) with large, apically blunt outer incisor, and inner incisor with three small denticles.

Maxillae (Fig. 3) with four blunt denticles on crown of galealaciniae ; one short, fine, simple seta on medial hump and row of four to five short, fine, simple setae near medial hump ; palp segment 1 slender, approximately $0.90 \mathrm{x}$ length of segment 2 ; segment 2 slender, slightly expanded distally.
Labium (Fig. 4) with glossae distally with six to eight long, fine, simple setae ; paraglossae distally with three rows of long, distally pectinate setae ; palp segment 1 approximately $1.67 \mathrm{x}$ length of segment 2 ; segment 2 approximately $1.5 \times$ length of segment 3 ; segment 3 with moderate lateral convexity and abundant minute, fine, simple setae scattered over surface.

- Thorax

Coloration medium yellow-brown to dark brown, with complex markings.

Pro- and mesonota medially without tubercles ; metanotum medially with row of long, fine, simple setae and posteriorly with submedial pair of minute tubercles.

Legs (similar to Fig. 15) medium yellow-brown to medium brown ; femora anterodorsally with row of long, somewhat robust, simple setae, and ventrally with sparse short, stout, simple setae ; tibiae anterodorsally with row of long, somewhat robust, simple setae, and ventrally with sparse short, stout, simple setae ; tarsi anterodorsally with row of long, somewhat robust, simple setae, and ventrally with sparse short, stout, simple setae ; tarsal claws with one row of seven to eight denticles.

- Abdomen

Coloration medium yellow-brown to dark brown, pattern generally as in Figure 5 ; tergum 1 medium yellow-brown, anterior and posterior margins dark brown ; tergum 2 dark brown, with posteromedial oblong medium yellow-brown markings ; tergum 3 dark brown, with sublateral subtriangular medium yellow-brown markings ; tergum 4 dark brown, with sublateral, narrow-oblong, medium yellow-brown markings ; tergum 5 anteriorly and medially medium yellow-brown, posterolaterally medium yellow-brown; terga 6 and 7 medium yellow-brown, with submedial pair of dark brown round spots; terga 8 and 9 medium yellowbrown, with sublateral pair of dark brown round spots ; tergum 10 medium yellow-brown.

Terga 1-5 or 1-6 submedially with pair of minute tubercles ; terga $6-10$ or 7-10 without tubercles.

Terga 1-10 with medial row of long, fine, simple setae.

Gills (Fig. 6) asymmetrical, broader basally than distally, untracheated, margins smooth and with minute, fine, simple setae.

Paraprocts (Fig. 7) marginally with numerous minute spines and distomedially with small subtriangular process. 
Caudal filaments pale to medium yellow-brown ; medial caudal filament approximately 0.03-0.05 x length of cerci.

\section{MALE SUBIMAGO}

Body length : 3.9-4.5 mm ; forewing length : 3.9-4.2 $\mathrm{mm}$; caudal filaments length : $6.8-7.1 \mathrm{~mm}$.

- Head

Coloration dark yellow-brown to dark brown.

Antennae cream.

Turbinate eyes dark yellow-brown; shape round.

- Thorax

Coloration medium to dark yellow-brown.

Forewings translucent dark gray.

Legs light to medium yellow-brown.

- Abdomen

Coloration medium yellow-brown to dark brown, pattern generally as in Figure 5 ; tergum 1 medium yellow-brown, anterior and posterior margins dark brown ; tergum 2 dark brown, with posteromedial oblong medium yellow-brown markings; tergum 3 dark brown, with sublateral subtriangular medium yellow-brown markings ; tergum 4 dark brown, with sublateral, narrow-oblong, medium yellow-brown markings ; tergum 5 anteriorly and medially medium yellow-brown, posterolaterally medium yellow-brown ; terga 6 and 7 medium yellow-brown, with submedial pair of dark brown round spots; terga 8 and 9 medium yellowbrown, with sublateral pair of round dark brown spots ; tergum 10 medium yellow-brown.

Small medial process present between genital forceps.

Caudal filaments cream to light yellow-brown.

FEMALE SUBIMAGO

Body length : $3.8-4.3 \mathrm{~mm}$; forewing length : 3.9-4.1 $\mathrm{mm}$; caudal filaments length : $6.7-7.2 \mathrm{~mm}$.

See description of male subimago.

\section{ADULT}

Unknown.

\section{- Material examined}

Holotype : Larva, Papua New Guinea, Morobe Prov, Clearwater Cr, nr Wau, 15-IX-1983, J. T. and D. A. Polhemus.

Paratypes : Three larvae, same data as holotype ; eight larvae, Papua New Guinea, Bulolo R, E of Wau, $2950 \mathrm{ft}, 15-\mathrm{X}-1964$, W. L. and J. G. Peters [mouthparts, forelegs, tergum 4 , and gill 4 of one larva, and mouthparts, forelegs, and paraproct of one larva moun- ted on slides (medium : Euparal)] ; five larvae, Papua New Guinea, Bulolo R, E of Wau, $2950 \mathrm{ft}, 18-X-1964$, W. L. and J. G. Peters ; larva, Morobe Prov, Kauli Cr, nr Wau, 17-IX-1983, J. T. and D. A. Polhemus.

Additional material : Six larvae, same data as holotype ; larva, Papua New Guinea, Morobe Prov, Wampit R, 18-IX-1983, D. A. Polhemus ; larva, Papua New Guinea, Morobe Prov, Wampit R, $10.7 \mathrm{~km}$ N Mumeng, 19-IX-1983 ; three male, two female subimagos, $\mathrm{Pa}$ pua New Guinea, Wau, Big Wau Cr, 3400 ft, 11-X1964 ; 14 larvae, Papua New Guinea, Bulolo R, E of Wau, $2950 \mathrm{ft}, 15-\mathrm{X}-1964$, W. L. and J. G. Peters ; 55 larvae, seven male, seven female subimagos ; Papua New Guinea, Bulolo R, E of Wau, $2950 \mathrm{ft}, 18-\mathrm{X}-1964$, W. L. and J. G. Peters ; six exuviae, four male subimagos, Papua New Guinea, Bulolo R, E of Wau $2950 \mathrm{ft}$, 25-X-1964, W. L. and J. G. Peters ; two larvae, Papua New Guinea, river nearby and similar to Omaheka R, 2200 m, 28-IX-1966, J. Illies ; larva, Papua New Guinea, Bulolo R, at jet with Karinga $\mathrm{Cr}$, NW of Wau, $3000 \mathrm{ft}, 12-\mathrm{X}-1964$, W. L. and J. G. Peters.

\section{- Etymology}

The specific epithet is Greek for «wooded valley.» It is a noun in apposition and is in allusion to the row of setae between the submedial tergal tubercles.

\section{- Discussion}

Larvae of $P$. bessa are easily distinguished from those of other species of Papuanatula by the presence of a pair of minute submedial tubercles on terga 1-5 or 1-6 and a medial row of setae on terga 1-10. Other characteristics that aid in distinguishing larvae of $P$. bessa include the abdominal color pattern (Fig. 5) and the distomedial subtriangular process of the paraproct (Fig. 7).

Male and female subimagos of $P$. bessa retain the general abdominal coloration of the larvae (Fig. 5), but do not show any remnants of the dorsal tubercles. As is the case with $P$. plana (see below), male subimagos have a sclerotized process between the genital forceps. We cannot say at this time, however, if the morphology of that process in $P$. bessa would be similar to that of $P$. plana, or if it will show significant differences.

2.3. Papuanatula copis Lugo-Ortiz \& McCafferty, n. sp.

\section{- Description}

LARVA

Body length : 6.0-6.5 mm ; caudal filaments length : 10-12 mm. 


\section{- Head}

Coloration medium yellow-brown to medium brown, with medium yellow-brown vermiform markings in frons and vertex.

Antennae approximately $1.5 \mathrm{x}$ length of head capsule.

Labrum (Fig. 9) dorsally with distal submarginal row of 30-35 long, fimbriate setae.

Hypopharynx as in Figure 10.

Left mandible (Fig. 11) with large, bladelike outer incisor, and inner incisor with three small denticles ; subtriangular process at base of mola undeveloped.

Right mandible (Fig. 12) with large, bladelike outer incisor, and inner incisor with three small denticles.

Maxillae (Fig. 13) with four blunt denticles on crown of galealaciniae ; one short, fine, simple setae at base of denticles ; one short, fine, simple setae on medial hump and row of four to five short, fine, simple seta near medial hump ; palp segment 1 robust, as long as segment 2 ; palp segment 2 slender.

Labium (Fig. 14) with glossae distally with six to eight long, fine, simple setae ; paraglossae distally with three rows of long, distally pectinate setae ; palp segments 1 and 2 equal in length ; palp segment 3 somewhat elongate, approximately $0.60 \mathrm{x}$ length of segment 2 , with well-developed lateral convexity and abundant minute, fine, simple setae scattered over surface.

\section{- Thorax}

Coloration dark yellow-brown to medium brown, with complex markings.

Pro- and mesonota medially without tubercles (short, acute, posteromedial tubercles present in immature specimens) ; metanotum (Fig. 16) medially with relatively long, robust, posteriorly oriented tubercle.

Legs (Fig. 15) medium yellow-brown to medium brown ; femora anterodorsally with row of long, somewhat robust, simple setae, and ventrally with sparse short, stout, simple setae ; tibiae anterodorsally with row of long, somewhat robust, simple setae, and ventrally with sparse short, stout, simple setae ; tarsi anterodorsally with row of long, somewhat robust, simple setae, and ventrally with sparse short, stout, simple setae ; tarsal claws with one row of seven to eight denticles.

\section{- Abdomen}

Coloration dark yellow-brown and medium brown ; terga 1-6 anteriorly and laterally dark brown ; terga 79 laterally dark brown ; tergum 10 generally dark yellow-brown. Sterna pale to medium yellow-brown.
Terga 1-8 with long, relatively robust, posteriorly directed medial tubercles ; terga 9-10 without medial tubercles (Fig. 16).

Gills (Fig. 17) ovoid, well tracheated, margins with minute serrations and minute, fine, simple setae.

Paraprocts (Fig. 18) marginally with numerous minute spines and distomedially without process.

Caudal filaments light to medium yellow-brown ; medial caudal filament vestigial.

\section{ADULT}

Unknown.

\section{- Material examined}

Holotype : Larva, Papua New Guinea, Morobe Prov, Poverty Cr, Mt Missim, 1600 m, 18-IX-1983, J. T. and D. A. Polhemus.

Paratypes : Two larvae, same data as holotype [antenna, mouthparts, forelegs, gill 4, paraproct mounted on slide (medium : Euparal)].

Additional material : Four larvae, same data as holotype.

\section{- Etymology}

The specific epithet is Latin for «short sword» It is in reference to the distinctive dorsal abdominal tubercles of the larval stage.

\section{- Discussion}

Papuanatula copis is readily distinguished from other species of the genus by its relatively large size and the presence of long, relatively robust, posteriorly directed medial tubercles on terga 1-8 (Fig. 16). Other characteristics that aid in distinguishing $P$. copis are the mandibular denticulation (Figs. 11, 12) and the relatively elongate and slender labial palps (Fig. 14).

\subsection{Papuanatula lenos Lugo-Ortiz \& McCafferty, n. sp.}

\section{- Description}

\section{LARVA}

Body length : 3.3-4.4 mm ; caudal filaments length : unknown.

- Head

Coloration medium yellow-brown, with no distinct markings.

Antennae approximately $1.5 \mathrm{x}$ length of head capsule.

Labrum (similar to Fig. 25) dorsally with distal submarginal row of eight to ten long, fimbriate setae.

Hypopharynx similar to Figure 10. 
Left mandible (Fig. 19) incisors forming one large, roughened bladelike incisor ; subtriangular process at base of mola well developed.

Right mandible (Fig. 20) incisors forming one large, roughened, bladelike incisor, and inner incisor with two minute denticles.

Maxillae (similar to Fig. 28) with four blunt denticles on crown of galealaciniae ; row of four to five short, fine, simple setae near medial hump ; palp segment 1 robust, approximately $0.95 \mathrm{x}$ length of segment 2 ; palp segment 2 robust, with short, fine, simple setae scattered over surface.

Labium (Fig. 21) with glossae distally with six to eight long, fine, simple setae ; paraglossae with three rows of long, distally pectinate setae ; palp segment 1 somewhat slender, approximately $1.43 \mathrm{x}$ length of segment 2 ; palp segment 2 approximately $1.1 \mathrm{x}$ length of segment 3 ; segment 3 with well-developed lateral convexity and abundant minute, fine, simple setae scattered over surface.

\section{- Thorax}

Coloration dark yellow-brown to medium brown, with no distinct markings.

Nota medially without tubercles.

Legs (Fig. 22) medium yellow-brown to medium brown ; femora anteriorly with large oblong to teardrop-shaped dark brown to purple black subproximal marking, posteriorly with long, broad purple-black dashes, anterodorsally with row of long, somewhat robust, simple setae, and ventrally with sparse short, stout, simple setae ; tibiae anterodorsally with row of long, somewhat robust, simple setae, and ventrally with sparse short, stout, simple setae ; tarsi anterodorsally with row of long, somewhat robust, simple setae, and ventrally with sparse short, stout, simple setae ; tarsal claws with one row of six to seven denticles.

\section{- Abdomen}

Coloration pale yellow-brown to dark brown, with pattern generally as in Figure 24 ; terga 1, 2, 9, and 10 pale to medium yellow-brown, posterior margin dark brown ; terga 3, 7, and 8 with trough-shaped dark brown markings (Fig. 23); tergum 4 with crownlike dark brown marking; terga 5 and 6 with long oblique sublateral dark brown dashes.

Terga medially without tubercles.

Gills (Fig. 24) oblong, lightly tracheated, margins smooth, with minute, fine, simple setae.

Paraprocts (similar to Fig. 35) marginally without spines and distomedially without process.
Caudal filaments basally light to medium yellowbrown (caudal filaments broken in all specimens).

ADULT

Unknown.

- Material examined

Holotype : Larva, Papua New Guinea, Wau, Hospital Cr, $3750 \mathrm{ft}, 20-\mathrm{X}-1964$, W. L. and J. G. Peters.

Paratypes : Two larvae, same data as holotype ; larva, Papua New Guinea, Western Highlands Prov, stream nr Murmur Pass, 7-IX-1983, J. T. and D. A. Polhemus [mouthparts, foreleg, paraproct on slide (medium : Euparal)].

Additional material : Seven larvae, same data as holotype.

- Etymology

The specific epithet is Greek for «trough.» It is a noun in apposition and an allusion to the abdominal color pattern of the larvae.

\section{- Discussion}

Papuanatula lenos is readily distinguished from other members of the genus by the large oblong to teardrop-shaped dark brown to purple-black subproximal marking on the anterior face of the femora (Fig. 22) and the abdominal color pattern (Fig. 23). The mandibular denticulation (Figs. 19, 20) and general labial morphology (Fig. 21) are also useful in distinguishing P. lenos.

\subsection{Papuanatula plana Lugo-Ortiz \& McCafferty,} n. sp.

\section{- Description}

LARVA

Body length : $3.7-4.1 \mathrm{~mm}$; caudal filaments length : 4.9-5.1 mm.

- Head

Coloration medium yellow-brown, with no distinct markings.

Antennae approximately $1.5 \mathrm{x}$ length of head capsule.

Labrum (Fig. 25) dorsally with distal submarginal row of 10-12 long, fimbriate setae.

Hypopharynx similar to Figure 10.

Left mandible (Fig. 26) with large, blunt outer incisor, and inner incisor with four minute denticles ; subtriangular process at base of mola well developed.

Right mandible (Fig. 27) with large, blunt outer incisor with three small denticles, and inner incisor with three small denticles. 
Maxillae (Fig. 28) with four blunt denticles on crown of galealaciniae ; row of four to five short, fine, simple setae near medial hump ; palp segment 1 robust, approximately $0.95 \mathrm{x}$ length of segment 2 ; palp segment 2 robust, with short, fine, simple setae scattered over surface.

Labium (Fig. 29) with glossae distally with six to eight long, fine, simple setae ; paraglossae distally with three rows of long, distally pectinate setae ; palp segment 1 approximately $1.27 \mathrm{x}$ length of segment 2 ; palp segment 3 with well-developed lateral convexity and abundant minute, fine, simple setae scattered over surface.

\section{- Thorax}

Coloration dark yellow-brown to medium brown, with no distinct markings.

Nota medially without tubercles.

Legs (similar to Fig. 15) medium yellow-brown to medium brown ; femora anterodorsally with row of long, somewhat robust, simple setae, and ventrally with sparse short, stout, simple setae ; tibiae anterodorsally with row of long, somewhat robust, simple setae, and ventrally with sparse short, stout, simple setae ; tarsi anterodorsally with row of long, somewhat robust, simple setae, and ventrally with sparse short, stout, simple setae ; tarsal claws with one row of seven to eight denticles.

\section{- Abdomen}

Coloration light yellow-brown to light brown ; terga 1-3 light yellow-brown, anteriorly and posteriorly medium yellow-brown to light brown ; terga 4-6 with faint yellow-brown crownlike marking ; tergum 4 posteriorly with narrow, dark brown transversal band ; terga 7-9 laterally light yellow-brown, medially, anteriorly, and posteriorly medium yellow-brown to light brown; tergum 10 light to medium yellow-brown.

Terga without tubercles.

Gills (Fig. 30) narrow-elongate, untracheated or poorly tracheated, margins smooth and without setae.

Paraprocts (similar to Fig. 35) marginally without spines and distomedially without process.

Caudal filaments light to medium yellow-brown ; medial caudal filament approximately 0.05-0.07 $\mathrm{x}$ length of cerci.

\section{MALE ADULT}

Body length : $3.8-4.1 \mathrm{~mm}$; forewings length : 4.5$4.7 \mathrm{~mm}$; caudal filaments length : $10.0-10.5 \mathrm{~mm}$.

- Head

Coloration medium to dark yellow-brown.
Antennae approximately as long as head capsule length ; scapes, pedicels, and filament cream to pale yellow-brown.

Turbinate eyes basally purple-brown, facets medium to dark yellow-brown; shape ovoid, enlarged.

- Thorax

Coloration light to medium yellow-brown.

Forewings as in Figure 31.

Legs cream to pale yellow-brown ; forefemora approximately $0.80-0.85 \times$ length of foretibiae.

\section{- Abdomen}

Coloration translucent white to pale yellow-brown ; segments 1-6 translucent white ; segment 4 dorsally with narrow dark brown to purple-brown transversal band ; segments 7-10 pale yellow-brown ; segments 78 sometimes with broad dorsomedial purple-brown longitudinal band.

Genitalia as in Figure 32.

Caudal filaments white to pale cream.

\section{FEMALE ADULT}

Body length : $3.4-3.8 \mathrm{~mm}$; forewings length : 4.9$5.0 \mathrm{~mm}$; caudal filaments length : unknown.

- Head

Coloration medium to dark yellow-brown.

Antennae approximately as long as head capsule length ; scapes, pedicels, and filament cream to pale yellow-brown.

- Thorax

Coloration medium to dark yellow-brown.

Forewings as in Figure 31.

Legs pale yellow ; forefemora subequal in length to foretarsi.

- Abdomen

Coloration medium to dark yellow-brown, lightly suffused with medium brown dots; segment 4 dorsally with narrow dark brown to purple-brown transversal band.

\section{- Material examined}

Holotype : Larva, Papua New Guinea, Bulolo R, E of Wau, $2950 \mathrm{ft}, 18-\mathrm{X}-1964$, W. L. and J. G. Peters.

Paratypes : Four larvae, same data as holotype ; larva, same data as holotype, except 15-X-1964 [mouthparts, forelegs, and paraproct on slide (medium : Euparal)].

Additional material : 68 larvae, same data as holotype ; 32 larvae, 34 male adults, same data as holotype, except 15-X-1964; 51 male adults, same data as holo- 
type, except 17-X-1964 ; male adult, same data as holotype ; 143 male, one female adults, same data as holotype, except 19-X-1964; two male, one female adults, same data as holotype, except $25-\mathrm{X}-1964 ; 168$ male adults, two female adults, same data as holotype, except 27-X-1964 ; larva, small side pool, Bulolo R, E of Wau, $2950 \mathrm{ft}, 15-\mathrm{X}-1964$.

\section{- Etymology}

The specific epithet is Latin for «plain» or «level.» It is adjectival and refers to the absence of dorsal tubercles in the larval abdomen.

\section{- Discussion}

Larvae of $P$. plana are readily distinguished from those of other species of Papuanatula by the mandibular denticulation (Figs. 26, 27) and the general labial morphology (Fig. 29). The relatively featureless abdominal color pattern and lack of dorsal tubercles can also aid in distinguishing $P$. plana.

Although no other adults of Papuanatula are known at this time, we expect the abdominal coloration and general morphology of the male genitalia (Fig. 32) to be of diagnostic value for $P$. plana.

\subsection{Papuanatula tuber Lugo-Ortiz \& McCafferty, n. sp. \\ - Description \\ LARVA}

Body length : 2.7-3.4 mm ; caudal filaments length : 3.0-3.2 mm.

\section{- Head}

Coloration medium yellow-brown, with no distinct markings.

Antennae approximately $1.5 \mathrm{x}$ length of head capsule.

Labrum (Fig. 33) dorsally with distal submarginal row of seven to nine long, fimbriate setae.

Hypopharynx similar to Figure 10.

Left mandible (similar to Fig. 26) with large, blunt outer incisor, and inner incisor with four minute denticles ; subtriangular process at base of mola well developed.

Right mandible (similar to Fig. 27) with large, blunt outer incisor with three small denticles apically, and inner incisor with three small denticles.

Maxillae (similar to Fig. 3) with four blunt denticles on crown of galealaciniae ; one short, fine, simple seta on medial hump and row of four to five short, fine, simple setae near medial hump ; palp segment 1 slender, approximately $0.90 \times$ length of segment 2 ; segment 2 slender, slightly expanded distally.
Labium (similar to Fig. 4) with glossae distally with six to eight long, fine, simple setae ; paraglossae distally with three rows of long, distally pectinate setae ; palp segment 1 approximately $1.67 \mathrm{x}$ length of segment 2 ; segment 2 approximately $1.5 \mathrm{x}$ length of segment 3 ; segment 3 with moderate lateral convexity and abundant minute, fine, simple setae scattered over surface.

\section{- Thorax}

Coloration medium yellow-brown to light brown, with no distinct markings.

Pronotum submedially with pair of small tubercles ; mesonotum medially without tubercles ; metanotum medially with small tubercle.

Legs (similar to Fig. 15), medium yellow-brown to medium brown ; femora anterodorsally with row of long, somewhat robust, simple setae, and ventrally with sparse short, stout, simple setae ; tibiae anterodorsally with row of long, somewhat robust, simple setae, and ventrally with sparse short, stout, simple setae ; tarsi anterodorsally with row of long, somewhat robust, simple setae, and ventrally with sparse short, stout, simple setae ; tarsal claws with one row of seven to eight denticles.

\section{- Abdomen}

Coloration pale yellow-brown to dark brown ; terga 1-4 medium brown, sublaterally with longitudinal broad dark brown band ; terga 5-9 pale yellow-brown, anteriorly with narrow medium to dark brown band ; terga 7-9 with submedial pair of small light brown round dots ; tergum 10 uniformly light brown.

Terga $1-8$ or $1-9$ with short, stout dorsally oriented medial tubercles (Fig. 34).

Gills (similar to Fig. 30) narrow-elongate, untracheated or poorly tracheated, margins smooth and without setae.

Paraprocts (Fig. 35) marginally without spines and distomedially without process.

Caudal filaments pale yellow-brown; medial caudal filament approximately $0.02-0.03 \mathrm{x}$ length of cerci.

\section{ADULT}

Unknown.

\section{- Material examined}

Holotype : Larva, Papua New Guinea, Bulolo R, E of Wau, $2950 \mathrm{ft}, 15-X-1964$, W. L. and J. G. Peters.

Paratypes : Larva, same data as holotype ; larva, same data as holotype, except 18-X-1964 [mouthparts mounted on slide (medium : Euparal)]. 
Additional material : Four larvae, same data as holotype, except 18-X-1964.

\section{- Etymology}

The specific epithet is Latin for «swelling.» It is a noun in apposition and refers to the presence of short, stout dorsal tubercles on the larval abdomen.

\section{- Discussion}

Papuanatula tuber is readily distinguished from other species of Papuanatula by the short and stout medial tubercles on terga $1-8$ or 1-9 (Fig. 34). The morphology of the labrum (Fig. 33) also aids in distinguishing $P$. tuber.

\subsection{Papuanatula vaisisi Lugo-Ortiz \& McCafferty, n. sp.}

Pseudocloeon sp. 2 Demoulin 1969 : 229.

\section{- Discussion}

Demoulin (1969) briefly described and sketchily illustrated three young larvae from New Britain as Pseudocloeon sp. 2. The specimens, however, clearly represent a new species of Papuanatula. We thus designate the three larval specimens as syntypes of the new species and formally name it as : Papuanatula vaisisi Lugo-Ortiz \& McCafferty, n. sp. Species characterization is illustrated by Demoulin (1969 : Fig. 4a-i), and we thereby invoke Article 73b of the International Code of Zoological Nomenclature in naming the species. The collection data of the syntypes is as follows : Archipel Bismarck, New Britain, Vaisisi, St. 83, 9-VII1962 (deposited in the Zoological Museum, Copenhagen, Denmark). The specific epithet is a noun in apposition and the name of the type locality.

Characteristics that distinguish $P$. vaisisi from other species of Papuanatula described herein include the relatively robust and short maxillary palps not reaching the galealaciniae (Fig. 36) and the poorly developed lateral convexity of segment 3 of the labial palps (Fig. 37).

\subsection{Key to the larvae of Papuanatula}

1. Labial palps segment 3 with poorly developed lateral convexity (Fig. 37) ; distribution : New Britain P. vaisisi

- Labial palps segment 3 with moderate to well developed lateral convexity (Figs. 4, 14, 21, 29) ; distribution : New Guinea 2

2. Abdominal terga medially with single tubercles (Figs. 16, 34) or submedially with minute paired tubercles
- Abdominal terga without tubercles 5

3. Abdominal terga 1-5 or 1-6 with submedial pair of minute tubercles; terga 1-10 with medial row of long, fine, simple setae ; abdominal color pattern as in Figure 5 P. bessa

- Abdominal terga 1-8 with single medial tubercles (Figs. 16, 34); terga 1-10 without medial row of long, fine, simple setae 3

4. Abdominal terga 1-8 with long, posteriorly oriented medial tubercles (Fig. 16) .................. P. copis

- Abdominal terga 1-7 or 1-8 with short, dorsally oriented tubercles (Fig. 34) ...................... P. tuber

5. Femora anteriorly with large oblong to teardropshaped dark brown to purple black subproximal marking (Fig. 22) ; abdominal color pattern as in Figure 24 P. lenos

- Femora anteriorly without oblong or teardrop-shaped marking ; abdominal color pattern not as above P. plana

\section{Acknowledgments}

We thank G. F. Edmunds, Jr. (Salt Lake City, Utah) for the donation of the material studied. We also thank A. Thomas (Toulouse, France) for his assistance in the preparation of the manuscript. This paper has been assigned Purdue Agricultural Research Program Journal No. 15736.

\section{References}

Demoulin G. 1969. - Les Éphéméroptères récoltés par la mission danoise du Noona Dan aus îles Philippines et Bismarck. Entomol. Medd. 37 : 225-241.

Harker. J. E. 1954. - The Ephemeroptera of eastern Australia. Trans. r. entomol. Soc. London 105 : 241-268.

Lugo-Ortiz C. R. \& McCafferty W. P. 1997. - A new genus and redescriptions for African species previously placed in Acentrella (Ephemeroptera : Baetidae). Proc. entomol. Soc. Wash. 99 : 429439.

McCafferty W. P. \& Waltz R. D. 1990. - Revisionary synopsis of the Baetidae (Ephemeroptera) of North and Middle America. Trans. Am. entomol. Soc. $116: 769-799$.

McCafferty W. P. \& Waltz R. D. 1995. - Labiobaetis (Ephemeroptera : Baetidae) new status, new North American species, and related new genus. Entomol. News $106: 19-28$.

Morihara D. K. \& McCafferty W. P. 1979. - Systematics of the propinquus group of Baetis species (Ephemeroptera : Baetidae). Ann. entomol. Soc. Am. 72 : 130-135.

Müller-Liebenau I. 1980. - Jubabaetis gen. n. and Platybaetis gen. $\mathrm{n}$, two new genera of the family Baetidae from the oriental region. Pp. 103-114. In : J. F. Flannagan \& K. E. Marshall (eds.), Advances in Ephemeroptera Biology. Plenum Publishing Corp., New York.

Ulmer G. 1920. - Neue Ephemeropteren. Arch. Naturgsch. 85 : 1 80.

van Bruggen A. C. 1957. - On two species of mayflies from the Wissel Lakes, Central New Guinea (Ephemeroptera). Nova Guinea $8: 31-39$. 
van Bruggen A. C. 1960. - On the generic position of Cloeon papuanum van Bruggen, 1957 (Ephemeroptera, Baetidae). Nova Guinea $10: 15-21$.

Waltz R. D. \& McCafferty W. P. 1985. - Redescription and new lectotype designation for the type species of Pseudocloeon, $P$. kraepelini Klapálek (Ephemeroptera : Baetidae). Proc. entomol. Soc. Wash. 87 : 800-804.

Waltz R. D. \& McCafferty W. P. 1987a. - New genera of Baetidae for some Nearctic species previously assigned to Baetis Leach (Ephemeroptera). Ann. entomol. Soc. Am. 80 : 667-670.
Waltz R. D. \& McCafferty W. P. 1987b. - Systematics of Pseudocloeon, Acentrella, Baetiella, and Liebebiella, new genus (Ephemeroptera : Baetidae). J. N. Y. entomol. Soc. 95 : 553-568.

Waltz R. D. \& McCafferty W. P. 1997. - New generic synonymies in Baetidae (Ephemeroptera). Entomol. News 108 : 134-140.

Waltz R. D., McCafferty W. P., \& Thomas A. 1994. - Systematics of Alainites n. gen., Diphetor, Indobaetis, Nigrobaetis n. stat. and Takobia n. stat. (Ephemeroptera : Baetidae). Bull. Soc. Hist. nat. Toulouse 130 : 33-36. 